\title{
アユに発生した非運動性ビブリオ菌による 流行病について
}

\author{
若林久嗣* ·塩瀬淳也 ${ }^{* *} \cdot$ 江草周三* . 富永正雄 ${ }^{* *}$ \\ (昭和 50 年 1 月 10 日受理)
}

1974 年 5 月末に長野県下のいくつかのアユ養殖池に異常整死が発生したので, 擎死魚および頻死魚の細 菌検査を行なったところ，いずれの検体からも単一と判断される非運動性桿菌が分離された。そこで，分離 菌の分類学的性状, 病原性, 薬剤感受性などを調べたところ, 非運動性の点を除きVibrio anguillarum に一致することが判明したので報告する。

\section{発 生 状 況}

長野県下, 佐久市, 上田市, 丸子町などのアユ養殖池で 5 月 28 日から 6 月 14 日をでに 8 件の発生が 確認された。なお，それ以前の 5 月 13 日にも同菌と思われる菌が分離されているが，カビ寄生の著しい 例であったので看過された。

病魚はいずれも琵琶湖から導入された稚アニで，導入直後から８日目までに発病し，擎死魚は外観症状 から三つに大別された。すなわち，(1) 体表に 0.5 1.5 cm の不定形のスレ様変色部を作り，進んだもの は皮㽞が崩落するもの (2) 体側微発赤腫脹部ないしは吹き出もの様患部を作るもの (3) 無症状のものて ある。発病池ではこれらの外観症状のものが混在し，また胸鰭基部や尾鰭に発赤したものがいずれの群にも 認められた。解剖所見としては腸管内に黄色粘液様物の充満が認められる他は顕著な症状は認め難く, とく 飞本病と同様に非運動性桿菌である P. plecoglosacida の感染魚の特徵的症状とされている肝臟の白斑形 成 ${ }^{11}$ は全く認められなかった。

発病経過の 1 例を举げると 5 万尾を収容した養殖池において，まず 1 日当り $2 \sim 3$ 尾の擎死が起り，その 後急激に增加して 2 3 日後には 1 日当り 200 尾の獘死率となった。放置すれば大量斃死に至るとみられ たので,ナリジクス酸を 1 日当り, 魚体重 $1 \mathrm{Kg}$ 当り, $20 \mathrm{mg}$ を連日経口投与したところ, 3 日目から䈐 死数が減少し，5７日後整死魚が無くなった。他の病例においても注注同様の経過をたどった。

\section{材料および方法}

病魚の体側患部, 肝臟, 腎臟などについて普通寒天培地による細菌分離を行なった。分離された菌株のう

表 1. 供試菌株 の 由.来

\begin{tabular}{|c|c|c|c|c|c|c|}
\hline 菌 株 & 分 離 年 月 & 日 & 分踓魚の症状* & 分離部位 & 所 在 & 地 \\
\hline PN 1 & 1974 年 5 月 28 & 日 & 体側発赤喱脹 & 腎＼cjkstart臟 & 上田市 & \\
\hline PN 2 & 5 月 29 & 日 & 体側スレ様 & " & 丸子町 & \\
\hline PN 3 & 5 月 29 & 日 & 体側吹き出物様 & $"$ & 佐久市 & A 池 \\
\hline PN 4 & 5 月 30 & 日 & 無症状 & " & 佐久市 & B 池 \\
\hline
\end{tabular}

*いずれも $3 \sim 4 \mathrm{~g}$ のアユで死亡直後のもの。

* 東京大学農学部

** 長野県水産指導所佐久支所 
ち表 1 に示した 4 株について一般性状試験, 病原性試験および薬剤感受性試験を行なった。一般性状試験 は常法に従って行なったが，原則として $25^{\circ} \mathrm{C} て ゙$ 培養し 1 週間観察した。

病原性試験はアニとウナギについて行なった。まず，アニに対しては普通寒天培地に $24 \sim 48$ 時間培養し た各供試菌を $0.85 \%$ 食塩水に $1 \mathrm{ml}$ 当り湿菌量 $1 \mathrm{mg}$ 懸渴し, 体重 $20 \sim 30 \mathrm{~g}$ のアュ 5 尾に $0.2 \sim 0.3 \mathrm{ml}$ 宛 $\left(1 \mathrm{mg}\right.$ 湿菌量 $/ 100 \mathrm{~g}$ 魚体重) 腹腔内注射を行ない $25^{\circ} \mathrm{C}$ の流水槽中に収容した。また，ウナギに対して も同様に菌液を調製し， $1 \mathrm{mg}$ 湿菌量 $/ 100 \mathrm{~g}$ 魚体重の割合で腹腔内と筋肉内とに各 1 尾宛注射した。供試 ウナギの体重は $100 \sim 200 \mathrm{~g}$ であった。実験水槽は水温 $25^{\circ} \mathrm{C}$ の通気された止水槽を用いた。

表 2. 分離菌の主な性状

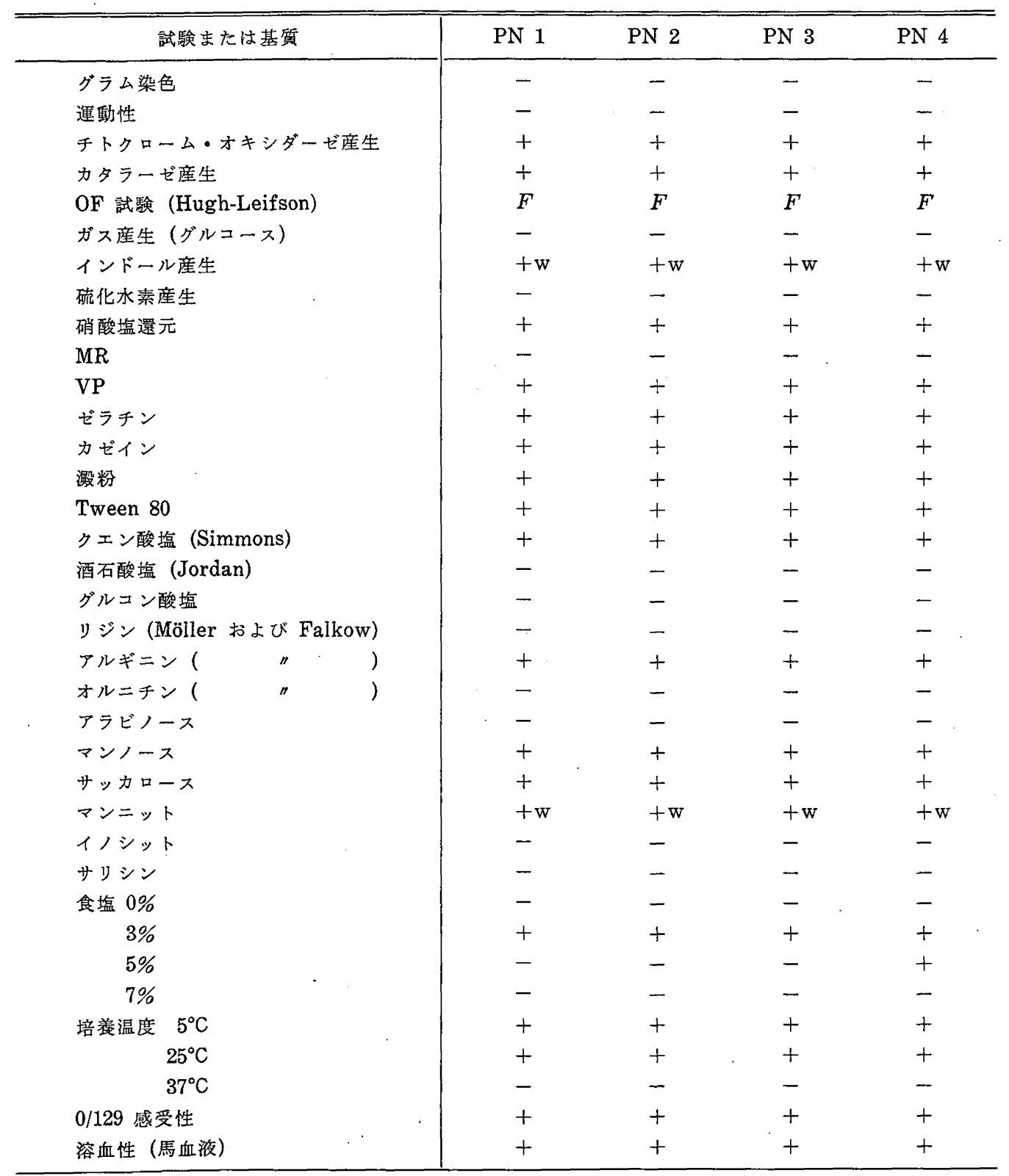


薬剤感受性試験はディスク法ないしは寒天希积法を用い常法に従って行なった。

結果

供試菌は普通寒天培地, トリプトソーヤ寒天培地などで比較的良好な発育を示し，約 $25^{\circ} \mathrm{C} 24$ 時間培養で 小型の円形, 半球状, 辺縁平滑, 半透明のコロニーを認める。小コロニーでは透明感が強く飴色がかってい るが，コロニーが大きくなると中心部から放射状に微細顆粒状の構造を作り白濁してくる。また，普通ブイ ヨン, トリプトソーヤ・ブイヨン, 食塩加ペプトン水などでも $25^{\circ} \mathrm{C} 24$ 時間培養で, 混濁が認められ, 僅 かな沈溊を作る。更に培養を続けると液面に粒状の菌塊が集むった形の膜を形成する。

菌体は $1 \sim 2 \times 0.5 \mu$ 前後の桿菌でやや彎曲したものが多く，また無芽胞，非抗酸性であった。表 2 に一 般性状ををとめて示したが，供試菌はグラム陰性の非運動性菌でチトクロームオキシダーゼを産生し，グル コースを発酵的に利用し，アルギニンを分解するがリジンを分解せず，また，0/129 に感受性を示し，食塩 を含まない培地には発育しないなどの特徵が認められた。

病原性試験の結果は供試 4 株ともアユおよびウナギを致死せしめた（表 3，4）。なお笮死魚の多くは顕著 な症状を示さなかったが，アュでは軽い浮腫や脱鱗および軽い内臓出血を伴うものもあり，また，ウナギで は筋肉注射部位の潰瘍と䐴鰖を含む腹面に強、発赤のみられたものがあった。また，獘死魚の内臓からはほ ぼ純粋に接種菌が再分離された。

表 3.アニに対する病原性哜験

\begin{tabular}{|c|c|c|c|}
\hline 試験番号 & 接 種 菌 $\left.{ }^{a}\right)$ & 供 試 萬 ${ }^{\mathrm{b})}$ & 致 死 魚) \\
\hline 1 & PN 1 あるいは PN 4 & 5 尾 & 4 尾 \\
\hline 2 & PN 2 & 5 尾 & 5 尾 \\
\hline 3 & PN 3 & 5 尾 & 3 尾 \\
\hline 4 & PN 4 あるいは PN 1 & 5 尾 & 3 尾 \\
\hline 5 & （対照） & 5 尾 & 0 尾 \\
\hline
\end{tabular}

a) 接種量はいずれも $1 \mathrm{mg}$ 湿菌量/100 $\mathrm{g}$ 魚体重で, 腹腔内注射。 対照群に対しては $0.85 \%$ 食塩水を菌液と同量注射。

b) 魚体重 $20 \sim 30 \mathrm{~g}$ 。

c) 4 日目まで。水温 $25^{\circ} \mathrm{C}$ 。

表 4. ウナギに対する病原性試験

\begin{tabular}{|c|c|c|c|c|}
\hline 試験番号 & 接種菌a) & 接種部位 & 供試魚体重 & 致死日 数 ${ }^{\mathrm{b})}$ \\
\hline 1 & PN 1 & 腹腔内 & $150 \mathrm{~g}$ & 生残 \\
\hline 2 & $\mathrm{PN} 2$ & $"$ & 160 & 5 日 \\
\hline 3 & PN 3 & " & 130 & 4 日 \\
\hline 4 & PN 4 & $"$ & 160 & 1 日 \\
\hline 5 & (対照) & $"$ & 120 & 生残 \\
\hline 6 & PN 1 & 背部筋肉内 & 180 & 生残 \\
\hline 7 & PN 2 & $"$ & 180 & 2 日 \\
\hline 8 & PN 3 & $"$ & 190 & 3 日 \\
\hline 9 & PN 4 & " & 190 & 2 日 \\
\hline 10 & (対照) & $"$ & 170 & 生残 \\
\hline
\end{tabular}

a) 接種量はいずれも $1 \mathrm{mg}$ 湿菌量 $/ 100 \mathrm{~g}$ 魚体重。対照には $0.85 \%$ 食塩水を $1 \mathrm{ml} / 100 \mathrm{~g}$ 魚体重で注射。

b) 6 日目まで, 水温 $25^{\circ} \mathrm{C}$ 
抗菌剤に対する感受性を表 5 にをとめて示した。なお，実際の投薬では既述のようにナルジクス酸の治療 効果が顕著であったが，クロムフェニコールやテトラサイクリンでは殆んど効果が認められなかった。

\section{考察}

養殖アニの非運動菌による疾病としては $P$. plecoglosacida 感染症が知られており1)，当初，今回の事例 もとれではないかと疑われたが，既述のように病魚の症状にかなりの相違が認められ，また，病原菌の性状 も明らかに異った。そこで分離菌の性状から病原菌の分類学的な位置を検討してみると，本菌はグラム陰性 捍菌でオキシダーゼを産生し, 糖を発酵的に分解し，0/129 に感受性があるところからVibrio 属に近い菌 と見当付けられる。Vibrio 属の種の 同定を Bergey's manual の第 8 版に従って試みるといくつかの未 確認の項目を残しているが，本菌は非運動性であること，クェン酸塩を利用すること，食塩 $0 \%$ で発育し ないことの 3 点を除けば V. anguillarum の記載に一致する性状をむつ。更に，これらの相違点のうちク エン酸塩利用と食塩 $0 \%$ での発育しない点は室賀ら゙が゙ンから分離し V. anguillarum と同定した多く の菌株においても同㥞の結果が報告されており，本質的な相違点ではないと判断される。一方，運動性が無 い点については分類学上Vibrio 属は極鞭毛を有する運動菌とされており,これまで非運動性のV.anguillarum の報告はない。しかし，V. cholerae で恃定の条件で継代を重ねていくと無鞭毛の変異株が作ら れることが知られており，本菌も何らかの条件下で V. anguillarum が鞭毛を失なった变異株ではないか と考えられる。

なお，今回の事例は長野県下にだけ確認されたものであるが, “発病はいずれも琵琶湖産稚魚を導入後間も

表 5. 分離菌の薬剤感受性

5-1. ディスク法によるもの

\begin{tabular}{|c|c|c|c|c|c|}
\hline & 剂(a) & PN 1 & $\mathrm{PN} 2$ & $\mathrm{PN} 3$ & PN 4 \\
\hline 1 & クロラムフェニコール & $H(21)$ & $+(17)$ & \# $(20)$ & H $(20)$ \\
\hline 2 & オキシテトラサイクリン & \# $(30)$ & \# (32) & \# (29) & \# (28) \\
\hline 3 & クロルテトラサイクリン & \# (32) & \# (27) & \# (31) & \# (33) \\
\hline 4 & テトラサイクリン & \# (35) & \# (31) & \# (36) & \# (33) \\
\hline 5 & ナリジクス酸 & \# $(50)$ & \# (49) & \# (50) & \# (52) \\
\hline 6 & スルファモノメトキシン & $+(17)$ & - & - & - \\
\hline 7 & スルファジメトキシン & $+(12)$ & - & - & - \\
\hline 8 & スルフイソミジン & - & - & - & - \\
\hline 9 & スルフイソゾール & H (20) & $\pm(18)^{b)}$ & $\pm(20)^{b)}$ & - \\
\hline 10 & フラゾリドン & \# (20) & \# (25) & $\#(22)$ & H (14) \\
\hline 11 & コリスチン & $H$ & $H$ & $H$ & H \\
\hline 12 & ジヒドロストレプトマイシン & + & + & + & + \\
\hline 13 & オレアンドマイシン & - & - & - & - \\
\hline 14 & ロイコマイシン & H & H & $H$ & $H$ \\
\hline 15 & カナマイシン & $H$ & \# & \# & H \\
\hline 16 & エリスロマイシン & + & + & + & + \\
\hline 17 & チアンフェニコール & - & - & - & - \\
\hline & オキソレニン酸 & H & $H$ & H & $H$ \\
\hline
\end{tabular}

a) 薬剤 No. 1〜10 については昭和ディスクを使用し, また薬丳 No. 11〜18 についてはトリディス

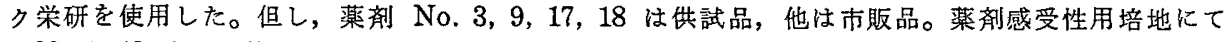
$25^{\circ} \mathrm{C}$ 約 48 時間培垱後マニュアルに従って判定。（）内の数值は阻止円の直径。

b) 阻止円内に薄い菌苔を認を。 
5-2. 寒天希秎法によるもの

\begin{tabular}{|c|c|c|c|}
\hline & 剂每) & 最小発育阻止濃度b) & \\
\hline 1 & =フルピリノール & $3.2 \gamma / \mathrm{ml}$ & \\
\hline 2 & ニフルプラジン & 0.8 & \\
\hline 3 & ニフルスチレン酸 & 3.2 & \\
\hline 4 & フラジリドン & $3.2<$ & \\
\hline 5 & チアンフェニコール & 400 & \\
\hline 6 & クロラムフェニコール & $12.5 \sim 50$ & \\
\hline 7 & クロルテトラサイクリン. & 6.25 & . \\
\hline 8 & テトラサイクリン & 25 & \\
\hline 9 & ナリジクス酸 & 0.1 & \\
\hline 10 & オキソレニン酸 & 0.05 & \\
\hline
\end{tabular}

a) いずれも市販品。1.フラネース顆粒 2. アイベット散 3 . エ ルパジン N 100. 4. NF ウエノＣ 205 . 動物用ネオマイゾン 6. ケミセチン液 50 7. 水産用オーレマイシン 8. 動物用エル ドマイシン可溶散 9 . ナリジクス酸（10 倍散）10. オキンレ ニン酸 (乳糖 20 倍散)

b) 普通寒天培地を基礎培地とし，2 倍希釈溶入法による。供試菌 株は PN 1, PN 2, PN 3, PN 4 でク口ラムフェニコールに 対する值が順に $50,25,50,12.5$ と異なった以外は 4 株とも 同值を示した。

なく起っており，起原が琵琶湖にあったようにも考えられ，再び同様事例が認められたならば広く調查して みる必要があろう。

\section{引用 文 献}

1) 楠田理一，三浦 航 (1972)：養殖アユから分離された病原性 Pasteurella 菌の性状について. 本誌 7 (1), 51-57.

2）室賀清邦・江草周三 (1973)：Vibrio anguillarum の性状に関する考察，本誌 8 (1)，10-25. 